\title{
Promiscuous T-cell epitopes of Plasmodium Merozoite Surface Protein 9 (PvMSP9) induces IFN-Y and IL-4 responses in individuals naturally exposed to malaria in the Brazilian Amazon
}

\author{
JC Lima-Juniora, DM Banic ${ }^{b}$, TM Tranc $^{\mathrm{c}}$, VSE Meyer ${ }^{\mathrm{c}}$, SG De-Simone ${ }^{\mathrm{d}}$, F Santos ${ }^{\mathrm{e}}$, LCS \\ Porto $^{f}$, MTQ Marques $^{f}$, A Moreno $^{\mathrm{C}, g}$, JW Barnwell ${ }^{\mathrm{h}}$, MR Galinski ${ }^{\mathrm{C}, \mathrm{g}}$, and J Oliveira- \\ Ferreira ${ }^{a}{ }^{*}$ \\ a Laboratory of Immunoparasitology, Institute Oswaldo Cruz, Fiocruz, Rio de Janeiro, RJ \\ b Laboratory of Malaria Research, Institute Oswaldo Cruz, Fiocruz, Rio de Janeiro, RJ \\ ${ }^{c}$ Emory Vaccine Center, Emory University, Atlanta, GA \\ d Laboratory of Biochemical of Proteins and Peptides, Institute Oswaldo Cruz, Fiocruz and \\ Department of Biochemistry and Molecular Biology, Institute of Biology, Universidade Federal \\ Fluminense, Rio de Janeiro, Brazil \\ e Department of Entomology, LACEN, Porto Velho, RO \\ ${ }^{f}$ Laboratory of Histocompatibility and Cryopreservation, State University of Rio de Janeiro, Rio de \\ Janeiro, RJ \\ 9 Division of Infectious Diseases, Emory University School of Medicine, Atlanta, GA \\ h Division of Parasitic Diseases, CDC/National Center for Infectious Diseases, Atlanta, GA
}

\section{Abstract}

Plasmodium vivax merozoite surface protein (PvMSP9) stimulates both cellular and humoral immune responses in individuals who are naturally infected by this parasite species. To identify immunodominant human T-cell epitopes in PvMSP9, we used the MHC class II binding peptide prediction algorithm ProPred. Eleven synthetic peptides representing predicted putative promiscuous T cell epitopes were tested in IFN- $\gamma$ and IL-4 ELISPOT assays using peripheral blood mononuclear cells (PBMC) derived from 142 individuals from Rondonia State, Brazil who had been naturally exposed to $P$. vivax infections. To determine whether the predicted epitopes are preferentially recognized in the context of multiple alleles, MHC Class II typing of the cohort was also performed. Five synthetic peptides elicited robust cellular responses, and the overall frequencies of IFN- $\gamma$ and IL-4 responders to at least one of the promiscuous peptides were $62 \%$ and $46 \%$, respectively. The frequencies of IFN- $\gamma$ and IL-4 responders to each peptide were not associated with a particular HLA-DRB1 allelic group since most of the peptides induced a response in individuals of 12 out of 13 studied allelic groups. The prediction of promiscuous epitopes using ProPred led to the identification of immunodominant epitopes recognized by PBMC from a significant proportion of a genetically heterogeneous population exposed to malaria

\footnotetext{
*Corresponding author: Joseli de Oliveira Ferreira, PhD, Laboratory of Immunoparasitology, Institute Oswaldo Cruz, Fiocruz, Rio de Janeiro, Brazil, Pavilhao Leonidas Deane, $4^{\text {th }}$ floor, Av. Brasil 4365 - ZIP: 21045-900, Rio de Janeiro, RJ - Brazil, Phone: +55-21-3865-8199, Fax:+55-21-3865-8198, lila@ioc.fiocruz.br.

Publisher's Disclaimer: This is a PDF file of an unedited manuscript that has been accepted for publication. As a service to our customers we are providing this early version of the manuscript. The manuscript will undergo copyediting, typesetting, and review of the resulting proof before it is published in its final citable form. Please note that during the production process errors may be discovered which could affect the content, and all legal disclaimers that apply to the journal pertain.
} 
infections. The combination of several such T-cell epitopes in a vaccine construct may increase the frequency of responders and the overall efficacy of subunit vaccines in genetically distinct populations.

\author{
Keywords \\ Plasmodium vivax; Merozoite Surface Protein-9; promiscuous T-cell epitopes
}

\title{
1. Introduction
}

Malaria caused by Plasmodium vivax is a major worldwide health problem with an estimated 80 to 300 million cases annually. Although the clinical profile of $P$. vivax malaria is not generally considered severe and a high mortality rate is not common, severe disease and mortality due to $P$. vivax are an increasing concern [1]. Notwithstanding, the substantial epidemiological impact of malaria caused by $P$. vivax can be quantified in terms of its significant economical burden in countries with emerging or developing nations [2-3]. Historically, basic and translational malaria research programs have been broadly focused on $P$. falciparum, and $P$. vivax investigations have received comparatively much less attention and support. In fact, among seventy two malaria vaccine candidates currently in a clinical development pathway only three are based on $P$. vivax antigens [4].

Effective immunity to malaria, whether studying $P$. falciparum, $P$. vivax, or animal model systems, seems to require both humoral and cellular immune responses, although the relative importance of each remains unclear. T helper cells are involved in the regulation of antibody production [5-6] and cytotoxic T lymphocyte (CTL) reactivity [6]. Effector T cells are also needed in the production of IFN- $\gamma$, which plays a role in controlling the liver-stage development and parasitemia peaks [7-8]. The identification of human CD4 T-cell epitopes within a protein is important in the context of vaccine design, because optimal T-cell epitopes delivered by vaccination would induce memory cells that could potentially be boosted by natural exposure to the parasite. However, the development of such vaccines is impaired due to the extensive polymorphism in human leukocyte antigens (HLA). The identification of universal T-cell epitopes, with promiscuous profiles of interaction with MHC class II molecules, enhances the possibility of developing subunit vaccines that could elicit immune responses in heterogeneous populations [9]. This will result in efficient response that transcends the barrier imposed by HLA polymorphism [10]. The use of in silico tools for mining such peptides circumvents the expensive and laborious experimental screening methods [11]. Because of their variable size, the prediction of peptides binding to HLA class II is more challenging as compared to HLA class I. HLA class II binding peptides are 9-22 amino acids long; with a binding core of 9 amino acids containing the primary anchor residues.

Plasmodium vivax merozoite surface protein-9 (PvMSP9) is a vaccine candidate that is expressed during schizogony and becomes organized on the surface of merozoites in the course of schizont development and segmentation. The $P$. vivax, $P$. cynomolgi and $P$. knowlesi msp-9 gene have typical eukaryotic signal peptides and diverse repeated motifs present immediately upstream of their termination codon. Another feature conserved among these proteins, including the $P$. falciparum MSP9 protein, is the positions of four cysteine residues near the $\mathrm{N}$-terminus, suggesting this conservation maintains structural and perhaps functional characteristics in the MSP-9 family. Rabbit polyclonal antisera raised against recombinantly expressed N-termini of $P$. knowlesi and $P$. vivax MSP-9 cross-react with the counterpart proteins in immunofluorescence and immunoblot assays [12-13]. 
We have reported that PvMSP9 contains B- and T-cell epitopes recognized by antibodies and T cells from individuals naturally exposed to P. vivax in the Brazilian Amazon [14]. Five synthetic peptides derived from the N-terminus of PvMSP9 stimulated T-cells to secrete IFN- $\gamma$ and IL-4 in from natives from the study population and a migrant population from a malaria free region of Brazil. In the present study we report the identification of peptide sequences containing promiscuous HLA class II epitopes derived from PvMSP9 that are capable of stimulating T cells from donors expressing various HLA genotypes and with confirmed exposure to $P$. vivax infections.

\section{Material and Methods}

\subsection{Study area and volunteers}

A cross-sectional cohort study was conducted involving 142 individuals from communities in the malaria endemic region of Rondonia state, Brazil, where $P$. vivax malaria accounts for more than $70 \%$ of all malaria cases in the last five years (Brazilian Ministry of Health, 2008). The individuals in the study population consist of rain forest natives who have resided in the malaria-endemic region for over 25 years (50\%) as well as transmigrants from several non-endemic areas of Brazil who have resided in the region for 10 years or more (38\%). Samples and survey data were collected during the dry months of June-August of 2004, coinciding with the period of increased malaria transmission in Rondonia State. Written informed consent was obtained from all adult donors or from parents of donors in the case of minors. The study was reviewed and approved by the Fundação Oswaldo Cruz Ethical Committee and the National Ethical Committee of Brazil.

\subsection{Epidemiological survey}

To evaluate epidemiological factors that may influence the cellular immune response against PvMSP-9, all donors were interviewed upon informed consent. Questions in the survey related to demographics, time of residence in the endemic area, personal and family histories of malaria, use of malaria prophylaxis, presence of malaria symptoms, and personal knowledge of malaria. Survey data was recorded and entered into a database created with Epi Info 2002 (Centers for Disease Control and Prevention, Atlanta, GA).

\subsection{Collection of human blood samples and malaria diagnosis}

Venous peripheral blood was collected into heparinized tubes, and peripheral blood mononuclear cells (PBMC) were isolated by Ficoll/Hypaque (Pharmacia, Piscataway, NJ) density gradient centrifugation and used in the ELISPOT assays within the first 12 hours after collection. Plasma was stored at $-20^{\circ} \mathrm{C}$ and thin and thick blood smears of all donors were examined for malaria parasites. Parasitological evaluation by examination of 200 fields at 1000X magnification under oil-immersion, all slides were examined by a researcher expertise in malaria diagnosis. Donors positive for $P$. vivax and/or $P$. falciparum at the time of blood collection were subsequently treated per the chemotherapeutic regimen recommended by the Brazilian Ministry of Health.

\subsection{ProPred analysis for PvMSP9 promiscuous T cell epitopes}

HLA-DR binding frames along the primary structure of PvMSP9 were detected by ProPred analysis. The amino acid sequence of PvMSP9 was scanned to identify promiscuous MHC binding peptides using virtual matrices designed for 51 HLA-DR alleles [15]. Eleven sequences were identified within the N-terminal region of PvMSP9 which were predicted to bind at least 40\% HLA-DR alleles included in the ProPed algorithm at a 3\% threshold. Synthetic peptides representing such putative T-cell epitopes were synthesized at the Laboratory of Biochemistry of Proteins and Peptides, Institute Oswaldo Cruz, Fiocruz. The 
complete amino acid sequences of five out of 11 synthetic peptides (including 3 overlapping regions) that induced the highest cellular response and the relative amino acid position were: 1) peptide $\mathrm{pE}\left(\mathrm{V}_{147}-\mathrm{K}_{159}\right)$, VVHKLNKKMKSLK; 2$)$ peptide $\mathrm{pH}\left(\mathrm{V}_{438^{-}}-\mathrm{D}_{449}\right)$,

VSLMASIDSMID; 3 ) peptide $\mathrm{pJ}\left(\mathrm{K}_{325} \mathrm{I}_{339}\right)$, KLKDILLRVLYKTYI; 4) peptide $\mathrm{pK}$ ( $\mathrm{P}_{434}-$ $\left.\mathrm{I}_{448}\right)$, PAEDVSLMASIDSMI and 5) peptide $\mathrm{pL},\left(\mathrm{A}_{443}-\mathrm{K}_{456}\right)$, ASIDSMIDEIDFYEK. The following six peptides the frequency of responders was very low (less than $3 \%$ ) and the relative amino acid position were: 1) peptide $\mathrm{pA}\left(\mathrm{M}_{1}-\mathrm{F}_{13}\right)$, MRVNIIIFSFVVF; peptide $\mathrm{pB}$ $\left(\mathrm{V}_{37}-\mathrm{C}_{50}\right)$, VNNYEKLFKVIKC; peptide $\mathrm{pC}\left(\mathrm{L}_{86}-\mathrm{V}_{99}\right)$, LMNDLKVGKNEHV; peptide $\mathrm{pD}$ $\left(\mathrm{Y}_{100}-\mathrm{N}_{112}\right)$, YGPNTNELKKIIH; peptide $\mathrm{pF}\left(\mathrm{F}_{341}-\mathrm{T}_{353}\right)$, LRVLYKTYINYRT; peptide $\mathrm{pG}$ $\left(\mathrm{L}_{371}-\mathrm{R}_{383}\right)$, LELGMKILFNKLR.

\subsection{ELISPOT assays}

Cells cultures were carried out in duplicate in nitrocellulose 96 well plates (MAHA S4510 Millipore, Billerica, MA) coated overnight at $4^{\circ} \mathrm{C}$ with $5 \mu \mathrm{g} / \mathrm{ml}$ capture anti-IFN- $\gamma$ monoclonal antibodies (MabTech, Stockholm - Clone D1K) or anti-IL-4 (Pharmingen, San Jose, CA - Clone MP4-25D2) in phosphate buffered saline. The plates were blocked with RPMI medium containing $10 \%$ fetal calf serum for at least $2 \sim \mathrm{h} .2 .5 \times 10^{5}$ cells were added to the ELISPOT plates in the presence of medium alone, $10 \mu \mathrm{g} / \mathrm{ml}$ of each PvMSP9 peptide or $1 \mu \mathrm{g} / \mathrm{ml}$ of phytohemaglutinin. Cells were stimulated for $24 \mathrm{~h}$ for IFN- $\gamma$ or $48 \mathrm{~h}$ for IL-4 at $37^{\circ} \mathrm{C}, 5 \% \mathrm{CO}_{2}$ under sterile conditions. After stimulation, plates were washed four times with PBS containing $0.05 \%$ Tween 20 (PBS-T) and incubated with either biotin-anti-human IFN- $\gamma$ Clone 7-B6-1 (MabTech) diluted in PBS or biotin-anti-human IL-4 Clone 12-1 NON0059 (Biosource International, Camarilla, CA) diluted in PBS-T containing 1\% fetal bovine serum (PBS-TF) for $3 \mathrm{~h}$ at $37^{\circ} \mathrm{C}$. The plates were washed four times with PBS-T and incubated with streptavidin-alkaline phosphatase (MabTech) in PBS-TF for $1 \mathrm{~h}$ at $37^{\circ} \mathrm{C}$. The plates were washed four times with PBS-T before development with 1-step NBT/BCIP (Pierce, Rockford, IL). Development was stopped by the addition of distilled water. IFN- $\gamma$ and IL-4 secreting cells appeared as blue spots that were counted with an Immunospot reader (Cellular Technology Ltd, Cleveland, $\mathrm{OH}$ ) using the Immunospot Software Version 3. ELISPOT responses were expressed as spot-forming cells (SFC) per 250,000 PBMCs. PHA $(1 \mu \mathrm{g} / \mathrm{ml})$ was used as a positive control. The assays were subsequently categorized as positive or negative depending on whether the mean number of SFC in the peptide stimulated wells was greater than the mean number plus twice the SD of SFC in the control wells with medium alone from the same donor. Therefore individuals presenting at least 20 for IFN- $\gamma$ and 10 for IL- 4 more SFCs $/ 2 \times 10^{5}$ PBMC in the experimental wells than in control were considered responders.

\subsection{HLA Typing of PBMC}

Genomic DNA was extracted and purified from PBMCs of volunteers using QIAamp blood kit (Qiagen Inc., Chatsworth, CA, USA) according to the manufacture recommendation. The amount of DNA obtained was quantified by spectrophotometry. Sequence-specific oligonucleotide probes (SSOPs) were used by Luminex Xmap technology in order to determine the HLA class II allelic groups of studied individuals. Briefly, the system is based on probe arrays bound to color-coded plastic microspheres, and locus-specific biotinylated primers for HLA-DRB1 and HLA-DQB1 loci (LABType, One Lambda Inc, Canoga Park, CA, USA). Biotinylated amplicons were denatured to ssDNA and incubated with DNA complementary probes immobilized on fluorescent coded microspheres (beads) followed by incubation with R-Phycoerythrin conjugated to streptavidin. After hybridization, the samples were analyzed with Luminex Flow Analysis equipment. The HLA analysis program deduces the HLA-DRB1 and HLA-DQB1 allelic groups. 


\subsection{Statistical analysis}

Analyses were done using Epi Info 2007 (CDC, Atlanta, GA), Instat or Prism 5 (GraphPad Software, San Diego, CA). Differences in medians for the study population data were tested by non-parametric Mann-Whitney test where appropriate. Student's t test was used to compare means of normally distributed data, and normalized transformations were performed on raw data before testing by one-way analysis of variance where appropriate. Differences in proportions were evaluated by chi-square $\left(\chi^{2}\right)$ test. Relationships between years of residence in the endemic area and number of past malaria infections or months since last known malaria episode were assessed with Spearman's rank correlation. Bipartition $\chi^{2}$ was used to evaluate the relationship between HLA-DRB1 and the frequency of cellular immune response. HLA-DRB1 and -DQB1 alleles were also analyzed for association with the IFN- $\gamma$ or IL-4 response to PvMSP9 peptides, and when appropriate a relative risk was calculated.

\section{Results}

\subsection{Epidemiological data}

The epidemiological and demographic data of the studied population have been described previously [14]. Briefly, the majority of the volunteers are natives of the Amazon forest or residents living in the state of Rondonia for approximately 20 years and transmigrants from non-endemic regions who have lived in malaria endemic regions for at least 10 years. All individuals were exposed to $P$. vivax and $P$. falciparum infections throughout the year. At the time of the blood collection the frequency of malaria infected individuals was very low, 11 individuals were infected with $P$. vivax and 4 with $P$. falciparum. However, the majority of our donors confirmed a prior history of malaria infections.

\subsection{IFN-y and IL-4 responses to PvMSP9 peptides}

Five out of the 11 synthetic peptides tested, predicted to be promiscuous, showed that the overall frequencies of IFN- $\gamma$ and IL-4 responders to at least one of the peptides were $61.2 \%$ and $49 \%$, respectively. The frequency of IFN- $\gamma$ responders was significantly higher than IL-4 for peptides $\mathrm{pE}(p=0.0006), \mathrm{pK}(p=0.0462)$ and $\mathrm{pL}(\mathrm{p}=0.0015)$, but no difference was observed for peptides $\mathrm{pH}$ and $\mathrm{pJ}$. When the pattern of the responses was examined, significant differences were observed, and the frequencies of positive responses induced by different peptides varied. In evaluating the IFN- $\gamma$ responses, the peptides $\mathrm{pE}$ and $\mathrm{pL}$ were more commonly recognized than $\mathrm{pH}, \mathrm{pJ}$ and $\mathrm{pK}(p<0.05)$. For IL-4 responses, no differences were observed among the synthetic peptides tested (Figure 1). The mean numbers of adjusted IFN- $\gamma$-SFC elicited by all tested peptides ( $\mathrm{pE}=43 \pm 23 ; \mathrm{pH}=39 \pm 14$; $\mathrm{pJ}=38 \pm 19 ; \mathrm{pK}=41 \pm 21 ; \mathrm{pL}=43 \pm 21)$ were significantly higher than IL-4-SFC $(\mathrm{pE}=21 \pm 8$; $\mathrm{pH}=25 \pm 11 ; \mathrm{pJ}=23 \pm 8 ; \mathrm{pK}=21 \pm 9 ; \mathrm{pL}=22 \pm 10$ ). A Venn diagram organizes the relationships among the cellular responses to overlapping peptides $\mathrm{pH}, \mathrm{pK}$ and $\mathrm{pL}$ (Figure 2). Of the 72 responders to $\mathrm{pL}, 49$ individuals also responded to $\mathrm{pK}$ and/or $\mathrm{pH}$; of the 55 responders to $\mathrm{pK}, 43$ individuals responded to $\mathrm{pH}$ and/or $\mathrm{pL}$; and finally, of the 52 responders to $\mathrm{pH}$, all but 4 individuals responded to the other overlapping peptides.

There were no statistically significant associations between the epidemiological profile of the studied population and either frequency of IFN- $\gamma$ responders or number of spots. However, the number of IL-4 spots generated after stimulation with all overlapping peptides $(\mathrm{pH}, \mathrm{pK}, \mathrm{pL})$ were higher in individuals who have lived in malaria endemic areas for more than 20 years when compared with those who have lived in such areas for less than 20 year $(p<0.0129)$, and the number of spots generated after $\mathrm{pL}$ stimulation was correlated with the time of residence in a malaria endemic area $(r=0.3421 ; p=0.0231)$. None of the 30 malarianaive control samples demonstrated significant IFN- $\gamma$ or IL- 4 cellular responses to the 5 
peptides tested. Both the malaria-exposed and malaria-naive groups responded similarly to PHA (577 \pm 211 IFN- $\gamma$ and $198 \pm 101$ IL-4 SFC).

\subsection{HLA genotyping of studied individuals}

PBMC of all donors were typed for HLA-DRB1 and HLADQB1 alleles in order to evaluate the promiscuous presentation of PvMSP9 peptides to T cells. The analysis of these 142 donors demonstrates that they represent a heterogeneous group of donors expressing several HLA allelic groups (Figure 3). We found 13 allelic groups in HLA-DRB ${ }^{*}$ and 5 groups in HLA-DQB $1 *$. There were two predominant HLA allelic groups in our studied population, HLA-DRB $1 * 04\left(19 \%\right.$ of all HLA-DR genotypes, $\left.\chi^{2}=6.043 ; p<0.0140\right)$ and HLA-DQB $1 * 03$ (47\% of all HLA-DQ genotypes, $\left.\chi^{2}=52.450 ; p<0.0001\right)$. The HLA-DRB $1 * 09$ and DQB $1 * 04$ presented the lower frequencies with $0.7 \%$ and $8.5 \%$ respectively.

\subsection{Evaluation of PvMSP9 peptides for promiscuous presentation}

The stimulation of PBMCs with the five synthetic PvMSP9 peptides induced IFN- $\gamma$ and IL-4 responses in malaria-exposed individuals with diverse HLA-DR and HLA-DQ backgrounds. Peptides $\mathrm{pE}, \mathrm{pH}, \mathrm{pJ}$, $\mathrm{pK}$ and $\mathrm{pL}$ induced IFN- $\gamma$ and/or IL-4 cellular response in all HLADRB1 allelic groups (tables 1 and 2), with the exception of HLA-DRB1*09. However, it is important to note that there was one individual in this group. The frequencies of IFN- $\gamma$ responders by HLA-DRB1 alleles range from $21.4 \%$ (pE in HLA-DRB $1 * 01$ individuals; $\mathrm{n}=28$ ) to $100 \%$ ( $\mathrm{pL}$ in HLA-DRB $1 * 08$ individuals; $\mathrm{n}=10$ ), however the frequency of IFN- $\gamma$ responders was not associated to a particular HLA-DRB1 allelic group. A similar profile was observed in HLA-DQB1, with a frequency of IL-4 responders ranged from $11.1 \%$ (pJ in HLA-DRB $1 * 11$ individuals; $\mathrm{n}=28$ ) to $100 \%$ ( $\mathrm{pH}$ in HLA-DRB1*10; $\mathrm{n}=2$ ). In evaluation of cellular response by HLA-DQB1, the frequencies of IFN- $\gamma$ responders ranged from $26.1 \%$ ( $\mathrm{pJ}$ in HLA-DQB $1 * 06 ; \mathrm{n}=46$ ) to $57.1 \%$ (pL in HLA-DQB $1 * 02, \mathrm{n}=28$ ) and the frequency of IL-4 responders from $18.8 \%$ ( $\mathrm{pJ}$ in HLA-DQB $1 * 05$ individuals; $\mathrm{n}=32$ ) to $41.2 \%(\mathrm{pH}$ in HLA-DQB $1 * 06$ individuals, $\mathrm{n}=34$ ), but there was no association between the positive or negative individuals and a particular HLA-DQB1 allele. The median number of IFN- $\gamma$ and/ or IL-4 spots generated in responders after stimulation with the five synthetic peptides did not differ significantly among the 13 HLA-DRB1 and the 5 HLA-DQB1 studied alleles.

\section{Discussion}

Plasmodium vivax merozoite surface protein 9 is a promising vaccine candidate antigen. Previous studies have demonstrated that (i) PvMSP9 is conserved among mice, primate and human Plasmodium species [12]; (ii) PvMSP9 recombinant proteins induce high titers of antibodies [13]; (iii) antibodies raised against PvMSP9 are capable of inhibiting merozoite invasion [12]; and (iv) malaria-exposed individuals present high frequency of natural antibody and cellular immune response against different regions of PvMSP9 [14]. Clinical trials based on a few selected malaria antigens have shown limited immunogenicity and a failure to induce long-lasting immunity, possibly due to the lack of effective T-cell epitopes in the constructs used as immunogens [16-17]. Nevertheless, there have been only a few Tcell epitopes reported from malaria antigens [18-24]. A major obstacle for identifying T-cell epitopes is the high level of polymorphism of HLA class II molecules. Thus, one of the most relevant steps for malaria vaccine development is to define T-cell epitopes that can interact promiscuously with a broad range of HLA-DR and/or HLA-DQ molecules.

Here we present the identification of five T cell epitopes in the vaccine candidate PvMSP9 that are capable of stimulating T cells from donors expressing various HLA genotypes and with confirmed exposure to $P$. vivax infections. 
Experimental screening methods to evaluate the presence of HLA restriction in immune response to vaccine candidates are expensive and time consuming. Computational prediction methods complement experimental studies, minimize the number of validation experiments, and significantly expedite the epitope mapping process [11]. Such methods have helped identify promiscuous epitopes within Leishmania [25], Mycobacterium tuberculosis [26] and HIV [27] antigens. Several promiscuous epitopes from pre-erythrocytic [22-23,28], asexual blood-stage [21,24,29], and gametocyte [20] antigens have been predicted and/or experimentally confirmed for $P$. falciparum. In contrast, only limited studies have focused on promiscuous epitopes for $P$. vivax $[19,30-32]$

In our study, eleven peptides were predicted by the ProPred algorithm to be promiscuous, but only five of them were recognized at high frequency by PBMCs from individuals living in malaria endemic areas. The recall response elicited by at least one of these five peptides was high for both IFN- $\gamma(64.1 \%)$ and for IL-4 (50.7\%) in comparison with the frequencies observed for other Plasmodium antigens such as PvTRAg40 [33], PfTRAP [34], PvDBP [35]. The frequency of T cells reactive to PvMSP9 is comparable to a study by Farouk et al. [36] that measured the cellular response to crude $P$. falciparum antigens by ELISPOT in a Malian population. Evaluating the numbers of IFN- $\gamma$ and IL-4 SFCs, we observed that IFN- $\gamma$ had higher numbers of secreting cells than IL-4 for all the synthetic peptides studied. No correlation between IFN- $\gamma$ response and malaria exposure was observed. However, IL-4 SFC produced upon peptide $\mathrm{pL}$ stimulation correlated positively with time of residence in the endemic area and the number of IL-4 spots generated after stimulation with all overlapping peptides $(\mathrm{pH}, \mathrm{pK}, \mathrm{pL})$ were higher in individuals who have lived in malaria endemic areas for more than 20 years when compared with those who have lived in such areas for less than 20 years. It is possible that variations in exposure may also explain variations in the type of naturally induced TH1 and TH2 immune responses to PvMSP9 [14]. Indeed, data reported by Troye-Blomberg et al. [37], showed a strong association between elevated IgG and IgE antibodies to blood-stage antigens with increased numbers of IL-4 secreting cells in individuals less susceptible to malaria infection. Similarly, correlations between the production of IL-4 in response to the $P$. falciparum malaria antigen Pf155RESA and protection against malaria were also reported [38].

The frequency and numbers of responders to overlapping peptides shows that the core sequence shared with peptides $\mathrm{pH}, \mathrm{pK}$ and $\mathrm{pL}$ (ASIDSMI) is highly immunogenic. However the presence of 23 individuals who present cellular response only to peptide $\mathrm{pL}$ suggest that this peptide may have two immunodominant epitopes, one in the overlapping core region and the second one in the carboxy-terminal region that is not shared with $\mathrm{pH}$ or pK (DEIDFYEK).

The evaluation of IFN- $\gamma$ and IL-4 production was used here to measure the recognition and activation of T cells by PvMSP9 putative promiscuous T-cell epitopes. To correlate the cellular response with the prevalence of MHC class II alleles, we determined the HLA antigen distribution among the study population. The observation of 13 allelic groups in the cohort suggests that the study population is heterogeneous, presenting a large variety of allelic groups. It was expected in our study mainly because Brazilian populations have peculiar features of a tri-hybrid populations formed with contribution of Caucasian, African, and native Amerindian origin, in which the phenotypic characteristics of each original population have been highly mixed. However the observation of high frequency of HLADR4 and HLA-DQ3 indicates that in this population the Amerindian HLA genotype is conserved [39]. Therefore, previous works already show the association with $\operatorname{IgG}$ responders to Plasmodium antigens and the HLA-DRB04 in this population [40-41], indeed studies with HLA polymorphism observed in several populations have been attributed to a pathogen induced selection [42-43]. 
The enrollment of populations with high HLA polymorphism but with a related degree of conservation and association with immune response with Plasmodium antigens is ideal to validate the prediction algorithm using PvMSP9. The lack of association with the frequency of IFN- $\gamma$ and IL- 4 cellular responses and the number of ELISpots generated after stimulation with the five PvMSP-9 predicted epitopes supports the recall cellular immune response reported in our previous study [14] and the promiscuous properties of the PvMSP9 derived peptides: $\mathrm{pE}, \mathrm{pH}, \mathrm{pK}, \mathrm{pJ}$ and $\mathrm{pL}$.

Several studies have suggested that single-epitope-based vaccines are not potent enough to induce full protection [30,44-45]. However, the identification of immunogenic and promiscuous epitopes within a vaccine candidate antigen is extremely important, since it is possible to formulate a vaccine composed of relevant epitopes from different antigens. Additionally, the combination of multiple B cell and T cell epitopes was shown to increase immunogenicity [46-48]. In conclusion the HLA-DR heterogeneity of the responding subjects and the prediction analysis using the ProPred server strongly suggest that these peptides was presented to T cells promiscuously. Thus the overall results suggest that HLA restriction will not be a problem if these peptides are used in a vaccine candidate.

\section{Acknowledgments}

This work was supported by Brazilian National Research Council - CNPq/PAPES, Fiocruz, National Institute of Health, the Yerkes National Primate Research Center Base Grant \# RR00165 awarded by the National Center for Research Resources of the National Institutes of Health, and NIH Grant \#RO1 AI0555994. Josué da Costa Lima Junior was the recipient of a CNPq Fellowship. We are grateful to all individuals that participate in this study for their cooperation and generous donation of blood, which made this study possible. We thank Eileen Farnon and Jennie Larson for the assistance during the sample collection. We thank the Secretary of Health of Rondonia State and the Laboratorio Central - LACEN of Rondonia for providing fieldwork support and the Program for Technological Development in Tools for Health-PDTIS/FIOCRUZ for use of its facilities.

\section{References}

1. Mueller I, Galinski MR, Baird JK, Carlton JM, Kochar DK, Alonso PL, et al. Key gaps in the knowledge of Plasmodium vivax, a neglected human malaria parasite. Lancet Infect Dis 2009 Sep; 9(9):555-66. [PubMed: 19695492]

2. Baird JK. Age-dependent characteristics of protection v. susceptibility to Plasmodium falciparum. Ann Trop Med Parasitol 1998 Jun;92(4):367-90. [PubMed: 9683890]

3. Price RN, Tjitra E, Guerra CA, Yeung S, White NJ, Anstey NM. Vivax malaria: neglected and not benign. Am J Trop Med Hyg 2007 Dec;77(6 Suppl):79-87. [PubMed: 18165478]

4. Galinski MR, Barnwell JW. Plasmodium vivax: who cares? Malar J 2008;7( Suppl 1):S9. [PubMed: 19091043]

5. Stephens R, Langhorne J. Priming of CD4+ T cells and development of CD4+ T cell memory; lessons for malaria. Parasite Immunol 2006 Jan-Feb;28(1-2):25-30. [PubMed: 16438673]

6. Good MF, Doolan DL. Immune effector mechanisms in malaria. Curr Opin Immunol 1999 Aug; 11(4):412-9. [PubMed: 10448141]

7. Yoneto T, Yoshimoto T, Wang CR, Takahama Y, Tsuji M, Waki S, et al. Gamma interferon production is critical for protective immunity to infection with blood-stage Plasmodium berghei XAT but neither NO production nor NK cell activation is critical. Infect Immun 1999 May;67(5): 2349-56. [PubMed: 10225894]

8. Luty AJ, Lell B, Schmidt-Ott R, Lehman LG, Luckner D, Greve B, et al. Interferon-gamma responses are associated with resistance to reinfection with Plasmodium falciparum in young African children. J Infect Dis 1999 Apr;179(4):980-8. [PubMed: 10068595]

9. Sinigaglia F, Guttinger M, Kilgus J, Doran DM, Matile H, Etlinger H, et al. A malaria T-cell epitope recognized in association with most mouse and human MHC class II molecules. Nature 1988 Dec 22-29;336(6201):778-80. [PubMed: 2462673] 
10. Sinigaglia F, Romagnoli P, Guttinger M, Takacs B, Pink JR. Selection of T cell epitopes and vaccine engineering. Methods Enzymol 1991;203:370-86. [PubMed: 1722274]

11. Lin HH, Zhang GL, Tongchusak S, Reinherz EL, Brusic V. Evaluation of MHC-II peptide binding prediction servers: applications for vaccine research. BMC Bioinformatics 2008;9( Suppl 12):S22. [PubMed: 19091022]

12. Barnwell JW, Galinski MR, DeSimone SG, Perler F, Ingravallo P. Plasmodium vivax, P. cynomolgi, and P. knowlesi: identification of homologue proteins associated with the surface of merozoites. Exp Parasitol 1999 Mar;91(3):238-49. [PubMed: 10072326]

13. Oliveira-Ferreira J, Vargas-Serrato E, Barnwell JW, Moreno A, Galinski MR. Immunogenicity of Plasmodium vivax merozoite surface protein-9 recombinant proteins expressed in E. coli. Vaccine 2004 May 7;22(15-16):2023-30. [PubMed: 15121316]

14. Lima-Junior JC, Tran TM, Meyer EV, Singh B, De-Simone SG, Santos F, et al. Naturally acquired humoral and cellular immune responses to Plasmodium vivax merozoite surface protein 9 in Northwestern Amazon individuals. Vaccine 2008 Dec 2;26(51):6645-54. [PubMed: 18832003]

15. Singh H, Raghava GP. ProPred: prediction of HLA-DR binding sites. Bioinformatics 2001 Dec; 17(12):1236-7. [PubMed: 11751237]

16. Keitel WA, Kester KE, Atmar RL, White AC, Bond NH, Holland CA, et al. Phase I trial of two recombinant vaccines containing the $19 \mathrm{kd}$ carboxy terminal fragment of Plasmodium falciparum merozoite surface protein 1 (msp-1(19)) and T helper epitopes of tetanus toxoid. Vaccine 1999 Oct 14;18(5-6):531-9. [PubMed: 10519944]

17. Nardin EH, Oliveira GA, Calvo-Calle JM, Castro ZR, Nussenzweig RS, Schmeckpeper B, et al. Synthetic malaria peptide vaccine elicits high levels of antibodies in vaccinees of defined HLA genotypes. J Infect Dis 2000 Nov;182(5):1486-96. [PubMed: 11023472]

18. Pimtanothai N, Parra M, Johnson AH, David CS, Katovich Hurley C. Assessing the binding of four Plasmodium falciparum T helper cell epitopes to HLA-DQ and induction of T-cell responses in HLA-DQ transgenic mice. Infection and immunity 2000 Mar;68(3):1366-73. [PubMed: 10678949]

19. Caro-Aguilar I, Rodriguez A, Calvo-Calle JM, Guzman F, De la Vega P, Patarroyo ME, et al. Plasmodium vivax promiscuous T-helper epitopes defined and evaluated as linear peptide chimera immunogens. Infect Immun 2002 Jul;70(7):3479-92. [PubMed: 12065487]

20. Contreras CE, Ploton IN, Siliciano RF, Karp CL, Viscidi R, Kumar N. Mapping of specific and promiscuous HLA-DR-restricted T-cell epitopes on the Plasmodium falciparum 27-kilodalton sexual stage-specific antigen. Infection and immunity 1998 Aug;66(8):3579-90. [PubMed: 9673236]

21. Daubenberger CA, Nickel B, Ciatto C, Grutter MG, Poltl-Frank F, Rossi L, et al. Amino acid dimorphism and parasite immune evasion: cellular immune responses to a promiscuous epitope of Plasmodium falciparum merozoite surface protein 1 displaying dimorphic amino acid polymorphism are highly constrained. Eur J Immunol 2002 Dec;32(12):3667-77. [PubMed: 12516559]

22. Doolan DL, Southwood S, Chesnut R, Appella E, Gomez E, Richards A, et al. HLA-DRpromiscuous T cell epitopes from Plasmodium falciparum pre-erythrocytic-stage antigens restricted by multiple HLA class II alleles. J Immunol 2000 Jul 15;165(2):1123-37. [PubMed: 10878392]

23. Moreno A, Clavijo P, Edelman R, Davis J, Sztein M, Sinigaglia F, et al. CD4+ T cell clones obtained from Plasmodium falciparum sporozoite-immunized volunteers recognize polymorphic sequences of the circumsporozoite protein. J Immunol 1993 Jul 1;151(1):489-99. [PubMed: 7686946]

24. Ohta N, Iwaki K, Itoh M, Fu J, Nakashima S, Hato M, et al. Epitope analysis of human T-cell response to MSP-1 of Plasmodium falciparum in malaria-nonexposed individuals. Int Arch Allergy Immunol 1997 Sep;114(1):15-22. [PubMed: 9303326]

25. Alves CR, Pontes de Carvalho LC, Souza AL, De Simone SG. A strategy for the identification of T-cell epitopes on Leishmania cysteine proteinases. Cytobios 2001;104(405):33-41. [PubMed: 11219729] 
26. Mustafa AS. Th1 cell reactivity and HLA-DR binding prediction for promiscuous recognition of MPT63 (Rv1926c), a major secreted protein of Mycobacterium tuberculosis. Scand J Immunol 2009 Mar;69(3):213-22. [PubMed: 19281533]

27. Fonseca SG, Coutinho-Silva A, Fonseca LA, Segurado AC, Moraes SL, Rodrigues H, et al. Identification of novel consensus CD4 T-cell epitopes from clade B HIV-1 whole genome that are frequently recognized by HIV-1 infected patients. AIDS 2006 Nov 28;20(18):2263-73. [PubMed: 17117012]

28. Parra-Lopez C, Calvo-Calle JM, Cameron TO, Vargas LE, Salazar LM, Patarroyo ME, et al. Major histocompatibility complex and $\mathrm{T}$ cell interactions of a universal T cell epitope from Plasmodium falciparum circumsporozoite protein. J Biol Chem 2006 May 26;281(21):14907-17. [PubMed: 16565072]

29. Vargas LE, Parra CA, Salazar LM, Guzman F, Pinto M, Patarroyo ME. MHC allele-specific binding of a malaria peptide makes it become promiscuous on fitting a glycine residue into pocket 6. Biochem Biophys Res Commun 2003 Jul 18;307(1):148-56. [PubMed: 12849994]

30. Caro-Aguilar I, Lapp S, Pohl J, Galinski MR, Moreno A. Chimeric epitopes delivered by polymeric synthetic linear peptides induce protective immunity to malaria. Microbes and infection/ Institut Pasteur 2005 Oct;7(13):1324-37. [PubMed: 16253535]

31. Herrera MA, de Plata C, Gonzalez JM, Corradin G, Herrera S. Immunogenicity of multiple antigen peptides containing Plasmodium vivax CS epitopes in BALB/c mice. Mem Inst Oswaldo Cruz 1994;89( Suppl 2):71-6. [PubMed: 7565136]

32. Fern J, Good MF. Promiscuous malaria peptide epitope stimulates CD45Ra T cells from peripheral blood of nonexposed donors. J Immunol 1992 Feb 1;148(3):907-13. [PubMed: 1370523]

33. Siddiqui AA, Bora H, Singh N, Dash AP, Sharma YD. Expression, purification, and characterization of the immunological response to a 40-kilodalton Plasmodium vivax tryptophanrich antigen. Infection and immunity 2008 Jun;76(6):2576-86. [PubMed: 18362136]

34. Flanagan KL, Plebanski M, Akinwunmi P, Lee EA, Reece WH, Robson KJ, et al. Broadly distributed T cell reactivity, with no immunodominant loci, to the pre-erythrocytic antigen thrombospondin-related adhesive protein of Plasmodium falciparum in West Africans. Eur J Immunol 1999 Jun;29(6):1943-54. [PubMed: 10382757]

35. Xainli J, Baisor M, Kastens W, Bockarie M, Adams JH, King CL. Age-dependent cellular immune responses to Plasmodium vivax Duffy binding protein in humans. J Immunol 2002 Sep 15;169(6): 3200-7. [PubMed: 12218138]

36. Farouk SE, Dolo A, Bereczky S, Kouriba B, Maiga B, Farnert A, et al. Different antibody- and cytokine-mediated responses to Plasmodium falciparum parasite in two sympatric ethnic tribes living in Mali. Microbes and infection/Institut Pasteur 2005 Jan;7(1):110-7. [PubMed: 15716067]

37. Troye-Blomberg M, Riley EM, Kabilan L, Holmberg M, Perlmann H, Andersson U, et al. Production by activated human T cells of interleukin 4 but not interferon-gamma is associated with elevated levels of serum antibodies to activating malaria antigens. Proceedings of the National Academy of Sciences of the United States of America 1990 Jul;87(14):5484-8. [PubMed: 2115172]

38. al-Yaman F, Genton B, Taraika J, Anders R, Alpers MP. Association between cellular response (IL-4) to RESA/Pf155 and protection from clinical malaria among Papua New Guinean children living in a malaria endemic area. Parasite immunology 1997 Jun;19(6):249-54. [PubMed: 9364554]

39. Volpini WM, Testa GV, Marques SB, Alves LI, Silva ME, Dib SA, et al. Family-based association of HLA class II alleles and haplotypes with type I diabetes in Brazilians reveals some characteristics of a highly diversified population. Hum Immunol 2001 Nov;62(11):1226-33. [PubMed: 11704284]

40. Pratt-Riccio LR, Lima-Junior JC, Carvalho LJ, Theisen M, Espindola-Mendes EC, Santos F, et al. Antibody response profiles induced by Plasmodium falciparum glutamate-rich protein in naturally exposed individuals from a Brazilian area endemic for malaria. Am J Trop Med Hyg 2005 Dec; 73(6):1096-103. [PubMed: 16354819]

41. Balduini CL, Bertolino G, Gamba G, Barosi G, Sinigaglia F, Noris P, et al. Platelet aggregation in platelet rich plasma and whole blood in 18 patients affected by idiopathic myelofibrosis. Eur $\mathbf{J}$ Haematol 1988 Sep;41(3):267-72. [PubMed: 3181398] 
42. Hill AV. Malaria resistance genes: a natural selection. Transactions of the Royal Society of Tropical Medicine and Hygiene 1992 May-Jun;86(3):225-6. 32. [PubMed: 1412635]

43. Hill AV. Molecular epidemiology of the thalassaemias (including haemoglobin E). Baillieres Clin Haematol 1992 Jan;5(1):209-38. [PubMed: 1596592]

44. Suhrbier A. Polytope vaccines for the codelivery of multiple CD8 T-cell epitopes. Expert Rev Vaccines 2002 Aug;1(2):207-13. [PubMed: 12901559]

45. Genton B, Corradin G. Malaria vaccines: from the laboratory to the field. Curr Drug Targets Immune Endocr Metabol Disord 2002 Oct;2(3):255-67. [PubMed: 12476490]

46. Hutchings CL, Birkett AJ, Moore AC, Hill AV. Combination of protein and viral vaccines induces potent cellular and humoral immune responses and enhanced protection from murine malaria challenge. Infection and immunity 2007 Dec;75(12):5819-26. [PubMed: 17908809]

47. Vasconcelos NM, Siddique AB, Ahlborg N, Berzins K. Differential antibody responses to Plasmodium falciparum-derived B-cell epitopes induced by diepitope multiple antigen peptides (MAP) containing different T-cell epitopes. Vaccine 2004 Dec 2;23(3):343-52. [PubMed: 15530679]

48. Pan W, Huang D, Zhang Q, Qu L, Zhang D, Zhang X, et al. Fusion of two malaria vaccine candidate antigens enhances product yield, immunogenicity, and antibody-mediated inhibition of parasite growth in vitro. J Immunol 2004 May 15;172(10):6167-74. [PubMed: 15128804] 


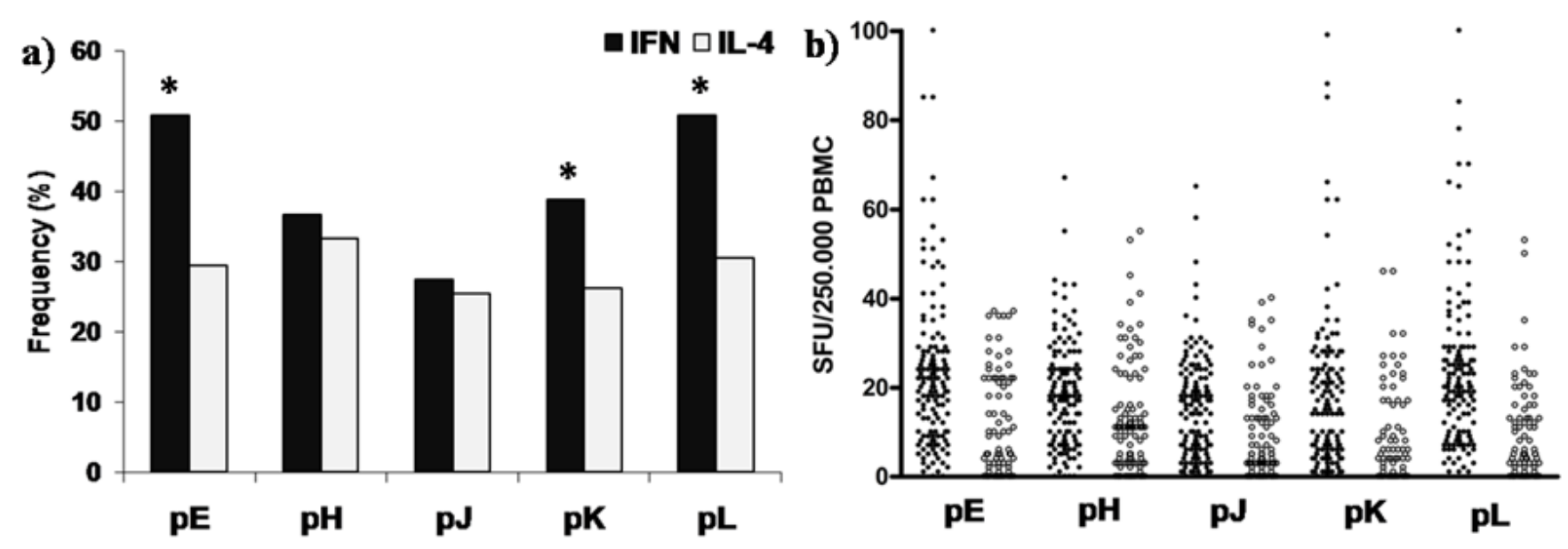

Figure 1.

Frequency of positive responders (a) and number of spots (b) in ELISpot IFN- $\gamma$ and IL-4 responses to PvMSP9 synthetic peptides ( $\mathrm{pE}, \mathrm{pH}, \mathrm{pJ}, \mathrm{pK}$ and $\mathrm{pL}$ ) in individuals naturally exposed to malaria infections. $(*)$ Significant differences $(p<0.01)$ for the comparison between the frequencies of IFN- $\gamma$ responders with IL-4 responders, for each peptide calculated using $\chi 2$ test. 


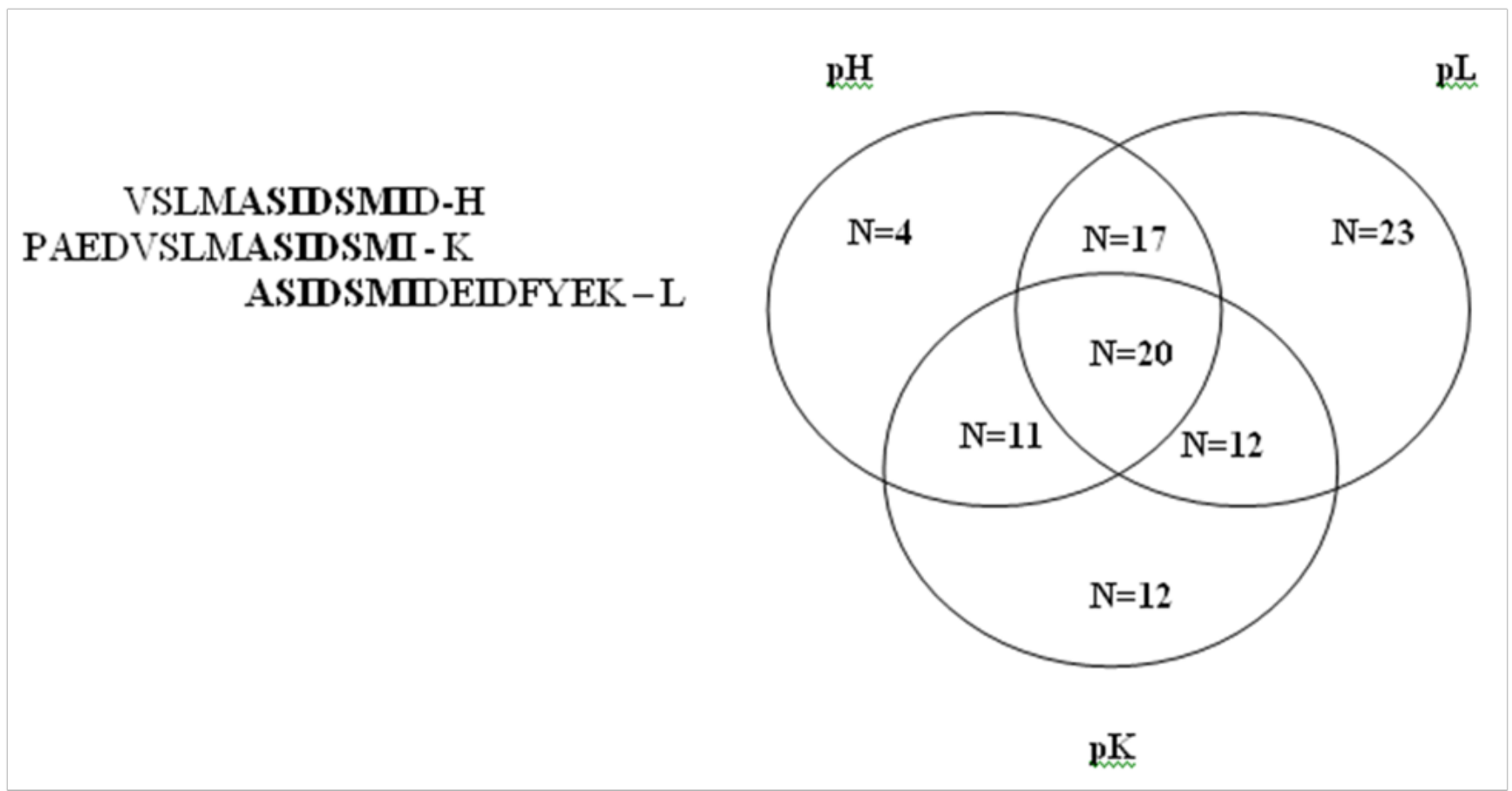

Figure 2.

Venn diagram showing the relationships among the cellular responses to overlapping peptides $\mathrm{pH}, \mathrm{pK}$ and $\mathrm{pL}$ sequences. Intersection points between the responders represent the number of positive individuals for two or three overlapping peptides. 

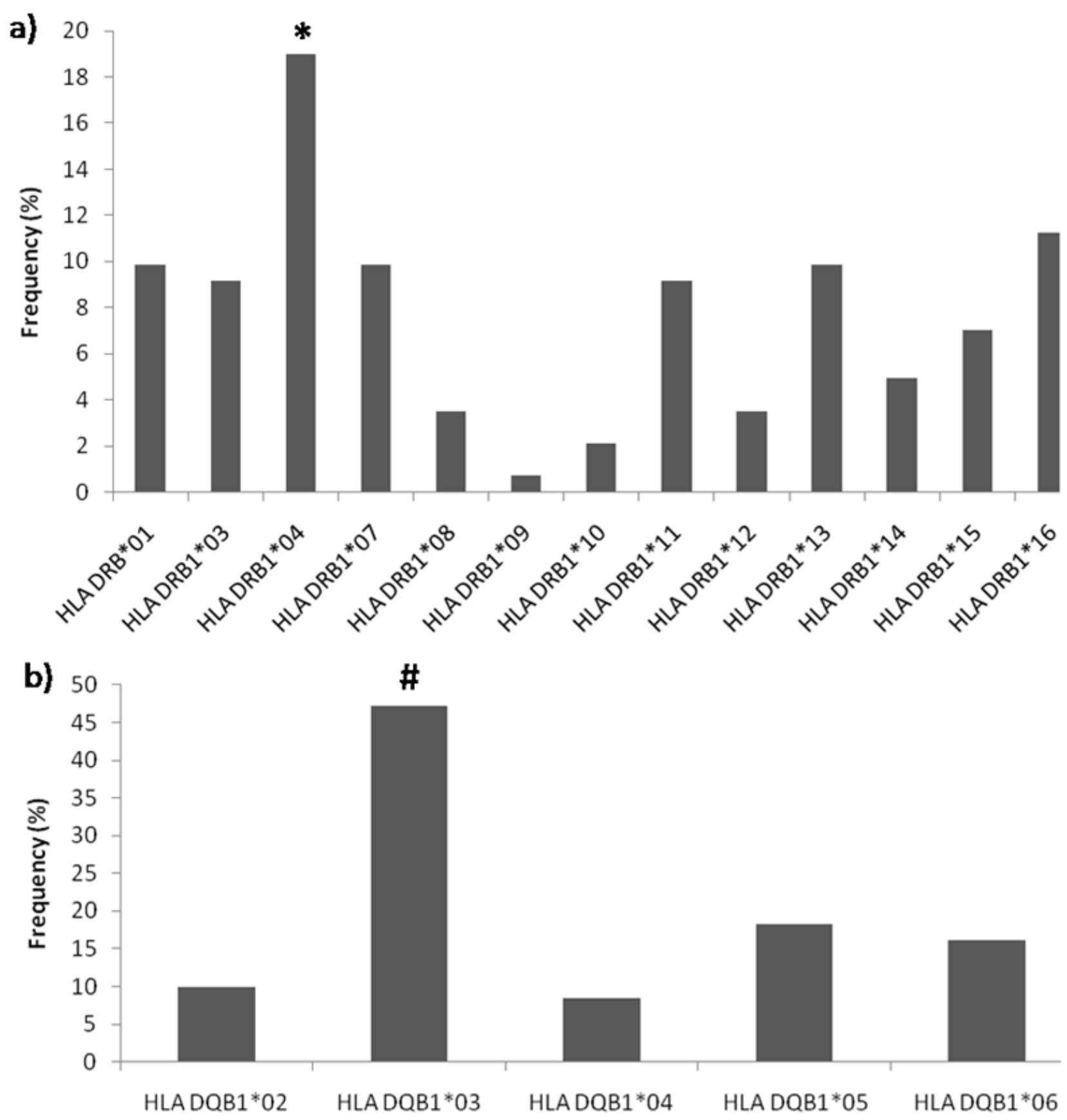

Figure 3.

Frequency of HLA-DRB1* (a) and HLA-DQB1 (b) alleles distribution in the 142 individuals studied. ${ }^{*}$ indicates that the proportion of HLA-DRB $1 * 04$ predominate over all others HLA-DRB1* studied alleles $\left(\chi^{2}=6.043 ; p<0.0140\right)$ and \# indicates that the proportion of DQB $1 * 03$ predominate over all other studied DQB $1 *$ alleles $\left(\chi^{2}=52.450\right.$; $p<0.0001)$. 
事主

量

* 言

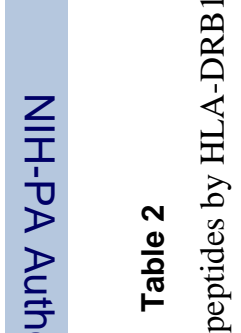

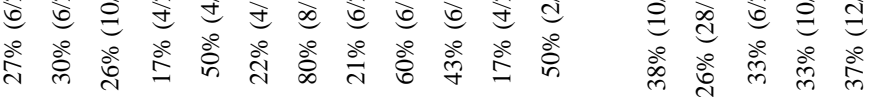

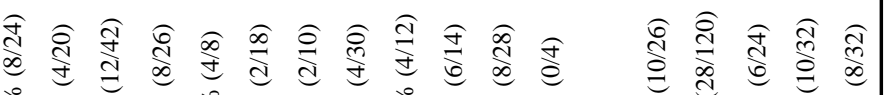

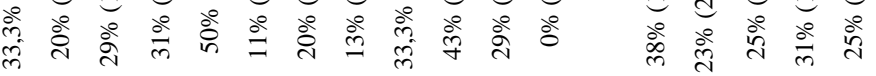

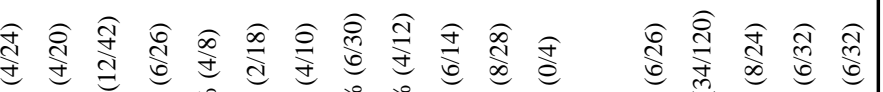
吾

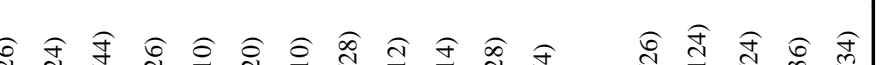

